\title{
Paul Mussen
}

\author{
Nancy Eisenberg ${ }^{2}$ \\ Arizona State University, EUA
}

Paul H. Mussen, um pioneiro no campo da psicologia do desenvolvimento, faleceu aos 78 anos no dia 7 de julho último, de câncer. Um dos primeiros psicólogos do desenvolvimento, o Dr. Mussen (com John Conger) escreveu o texto clássico "Child Development and Personality" (1956), que foi a obra padrão na área por 30 anos. Ele fazia parte de um pequeno grupo de psicólogos do desenvolvimento, que levou a área de uma orientação behaviorista, de estímulo-resposta, para uma abordagem focada na socialização parental e questões de internalização. Ele editou duas edições da "biblia" da área, o "Handbook of Child Psychology" (publicado em 1970 e em 1983), além de muitos outros livros, entre os quais "The Psychological Development of the Child" (1963), "The Roots of Caring, Sharing and Helping" (com Nancy Eisenberg, 1977) e "The Roots of Prosocial Behavior in Children" (com Nancy Eisenberg, 1989). Muitos de seus livros foram traduzidos para outras línguas e tiveram múltiplas edições.

Paul Mussen nasceu em 21 de março de 1922, em Paterson, New Jersey, Estados Unidos. Ele cresceu em Connecticut e freqüentou a Universidade de Connecticut, em Storrs, até receber uma bolsa da Universidade de Stanford em 1939. Durante a II Guerra Mundial, Mussen serviu como um guarda-marinha no serviço de Inteligência Naval da marinha americana em Washington, D.C, no Hawaii e em San Francisco. Ele completou seu Ph.D. em Psicologia na Universidade de Yale em 1949, fazendo amizades que durariam por toda a vida com colegas e professores, inclusive com seu colaborador John Conger. Inicialmente ele trabalhou na Universidade de Wisconsin, em Madison, de 1949 a 1951, e após na Obio State University em Columbus até 1955. Nesta universidade ele conheceu e se casou com Ethel Foladare, uma estudante de pós-graduação que lá completou seu doutorado.

Em 1956, Mussen foi para a Universidade da California em Berkeley onde trabalhou até sua aposentadoria (1986). Nesta universidade, ele foi diretor do Instituto de Desenvolvimento Humano, de 1971 a 1980 e retornou de sua aposentadoria, em 1987, para

EUA

${ }^{2}$ A editora agradece ao Prof. Claudio Simon Hutz, a traduç̃o para o Português. atuar como como diretor pró-tempore deste Instituto. Ele recebeu uma bolsa da Fundação Fulbright, em 1960, para fazer pesquisa em Florença, na Itália, e, em 1968, foi escolhido para ser Fellow do Centro de Estudos Avançados em Ciências Comportamentais em Stanford.

Mussen lecionou e deu consultorias para universidades em vários países da Europa, Egito, Nigéria, Israel e Oriente Médio, Índia, Paquistão, Japão, Nova Zelândia e Austrália. Ele foi um dos primeiros professores americanos a lecionar na China, após a Revolução Cultural. Posteriormente, ele desempenhou um importante papel na revitalização dos programas de psicologia social e do desenvolvimento nas universidades chinesas.

Por ser uma fonte de força, liderança e de apoio a muitos em sua profissão, Mussen atuou como membro da unidade revisora de propaganda direcionada a crianças do Better Business Burean por muitos anos, elevando os padrões de publicação e propaganda em programas de televisão direcionados a crianças. Ele foi também presidente da Western Psychological Association de 1973 a 1974, e da Divisão de Psicologia do Desenvolvimento da American Psychological Association de 1977 a 1978.

Recentemente, entre a coleção de livros que ele tanto amava, e com uma vista de São Francisco e da Golden Gate, ocorreu uma reunião informal de amigos, vizinhos, familiares e colegas em sua casa para expressar afeição e estima a esse humanista espirituoso. Muitos dos que conheceram Paul exercendo papéis profissionais, tiveram o privilégio de sua amizade. Ele não foi apenas meu mentor, mas também meu amigo pessoal. Paul era uma pessoa calorosa, envolvente, que dava liberalmente seu tempo, conselho e apoio a todos. Ele tinha um gosto pela vida que era contagiante. Ele fará muita falta para seus amigos, colegas, ex-alunos e familiares.

\section{Referências}

Eisenberg, N. \& Mussen, P. (1989). The roots of prosocial behavior in cbildren. Campidge Con

ussen, P. (Org.). (1970). Carmichael's manual of cbild psychology. New York:
W. Wiley.

Mussen, P. (Org.). (1983). Handbook of cbild p.sychology. New York: Wiley.

Mussen, P. (Org.). (1963). The prychological development of the child New York Wiley.

Mussen, P. \& Conger, J. (1956). Child development and personality. New York: Harpe

Lussen, P. \& Eisenberg, N. (1977). The roots of caring, sharing and helping. San Francisco: Freeman. 


\section{Paul Mussen}

Nancy Eisenberg

Arizona State University, EUA

Paul H. Mussen, a pioneer in the field of developmental psychology, died at 78 On July 7, 2000, from cancer. One of the early developmental psychologists, Dr. Mussen (with John Conger) wrote the classic text, "Child Development and Personality"(1956), which was the standard in the field for 30 years. He was among a small group of developmentalists who moved the field from a behaviorist, stimulus-response orientation to a focus on parent socialization and issues of internalization. He edited two editions of the "bible" of the field, "The Handbook of Child Psychology" (published 1970 and 1983), and published numerous other books, including "The Psychological Development of the Child" (1963), "The Roots of Caring, Sharing and Helping" (with Nancy Eisenberg, 1977), and "The Roots of Prosocial Behavior in Children" (with Nancy Eisenberg, 1989). Many of his books were translated into other languages and went through multiple editions.

Paul Mussen was born March 21, 1922, in Paterson, New Jersey. He grew up in Connecticut and attended the University of Connecticut at Storrs until he received a scholarship to Stanford University in 1939. Mussen served as an ensign in Naval Intelligence in the $\mathrm{Navy}$ in Washington, D.C, Hawaii, and San Francisco in World War 11. He completed his $\mathrm{PhD}$ in psychology at Yale University in 1949, forming lifelong friendships with fellow students and faculty, including his future collaborator, John Conger. He first taught at the University of Wisconsin, Madison, from 1949-51 and then at Ohio State University in Columbus until 1955, where he met and married Ethel Foladare, a graduate student who earned her $\mathrm{PhD}$ at Ohio State.

Dr. Mussen moved to University of California, Berkeley in 1956, where he worked until retirement (1986). At UC Berkeley, he served as director of the Institute of
Human Development from 1971-80 and returned from retirement to serve as acting director in 1987 . He received a Fulbright Award in 1960 for research in Florence, Italy, and in 1968 was selected as a Fellow of the Center for Advanced Study in the Behavioral Sciences at Stanford.

Dr. Mussen lectured and consulted at universities throughout Europe, Egypt, Nigeria, Israel and the Middle East, India, Pakistan, Japan, New Zealand and Australia. He was one of the first American professors to teach in China following the Cultural Revolution. He later played an role in revitalizing the programs on social and developmental psychology in Chinese universities.

A source of strength, leadership and support to many in his profession, Mussen served as a member of the children's advertising review unit of the Better Business Bureau for several years, upholding standards of writing and advertising on children's television. He was president of the Western Psychological Association from 1973-74 and the American Psychological Association's division of developmental psychology from 1977-78.

Amid his beloved collection of books, facing a view of San Francisco and the Golden Gate, an informal gathering of friends, neighbors, family, neighbors, friends, and colleagues at his home recently voiced affection and esteem for the witty humanist. Many who knew Paul in professional roles had the privilege of his friendship. $\mathrm{He}$ was not only my mentor, but my close friend. Paul was a warm, engaging person who gave freely of his time, advice, and support to all. He had a zest for life which was contagious. He will be sorely missed by his many friends, colleagues, and past students, and his family.

Texto publicado a convite da Editora Profa. Sívia H. Koller, em homenagem a um dos principais nomes da Psicologia do Desenvolvimento. Recebido em 16.08.2000

Sobre a autora:

Nancy Eisenberg é Professora Regente de Psicologia, na Arizona State University, Tempe, Arizona,

EUA. 